\title{
The biodiverse rotifers (Rotifera: Eurotatoria) of the floodplain wetlands of Barak valley of Assam, Northeast India
}

\author{
B.K. SHARMA*, S. SHARMA \\ Bhushan Kumar Sharma \& Sumita Sharma Department of Zoology, North-Eastern Hill University, Shillong \\ - 793 022, Meghalaya, India; *profbksharma@gmail.com (corresponding author)
}

\begin{abstract}
The present analysis of alpha diversity of Rotifera of the floodplain wetlands of Barak valley, south Assam, northeast India (NEI) reveals 170 species, belonging to 39 genera and 19 families, with three species new to the Indian sub-region and two species new to Assam state. The rich and diverse rotifer assemblages comprise $\sim 70 \%, \sim 57 \%$ and $\sim 39 \%$ of total species of the Phylum known till date from Assam, NEI and India, respectively and thus affirm habitat and ecological heterogeneity of the Barak River floodplain wetlands. The elements of global biogeographic importance include one Australasian, eight Oriental, 10 Paleotropical, one Indo-Chinese, one cosmo (sub) tropical and four other species, and $\sim 37 \%$ species merit regional distribution interest for India with $\sim 13 \%$ exclusively reported from NEI. Lecanidae $(\sim 30 \%)$ and Brachionidae $\approx$ Lepadellidae $(\sim 32 \%)$ largely contribute to the rotifer richness; Trichocercidae $>$ Testudinellidae are notable $(\sim 15 \%)$, and Notommatidae, Euchlanidae, Mytilinidae, Trichotriidae and Trochosphaeridae collectively form 16.5\%. Lecane is the most speciose genus; Lepadella $>$ Brachionus $=$ Trichocerca include $\sim 32 \%$ species, while Testudinella $>$ Keratella deserve mention. Rotifera of the Barak floodplains exhibit the littoral-periphytonic nature, several small sized species and tropical character.
\end{abstract}

Keywords. Barak River, biodiversity, composition, important taxa, richness, south Assam.

\section{INTRODUCTION}

$\mathrm{R}$ otifera or Rotatoria, an integral component of aquatic metazoans, have been recorded from distant parts of India since the pioneering work of Anderson (1889). Nevertheless, the Indian literature still lacks attention on regional faunal diversity of these 'wheel animalcules' except for NEI the most rich and Rotifera biodiverse region of India (Sharma \& Sharma 2014a, 2017). Importantly, Assam state of NEI, a part of the IndoMyanmar biodiversity hotspot, merits attention as 'the Assam-gateway' which is recognized as a unique phase in the biogeographic evolution of India (Mani 1974, Ranga Reddy 2013). Further, this state is characterized by the fluvial floodplain wetlands of the Brahmaputra and Barak Rivers; the former are hypothesized as globally rich rotifer habitats (Sharma \& Sharma 2008, 2014b, Sharma et al. 2018).

In light of the salient highlights of Assam, we extend our studies to the floodplains of the Barak river basin of south Assam (known as Barak valley) which is yet practically unexplored with regards to rotifer fauna (Sharma \& Sharma 2014a). This lacuna assumes more prominence in spite of several limnological works (Kar \& Kar 2013, Gupta \& Devi 2014, Narzary et al. 2015, Das \& Kar 2016, Kar \& Kar 2016a, 2016b, Das et al. 2018, Kar et al. 2018) from Barak valley but loaded with 'ad-hoc' rotifer inventories due to lack of species determinations, incomplete species lists, overlooking identifications of small taxa, inadequate sampling and lack of taxonomic expertise. The present study thus provides the first exhaustive assessment of the rotifer biodiversity from the floodplain wetlands of the Barak River basin. An inventory of the observed species is presented, and various new records and interesting species are illustrated to warrant validations routinely lacking for the rotifer taxa reported from India (Sharma \& Sharma 2014a, 2017). Remarks are made on species composition, richness and distribution, and important taxa. The results mark a useful contribution to biodiversity of Rotifera of 
India, the floodplain wetlands of this country as well as that of (sub) tropical floodplains.

\section{MATERIALS AND METHODS}

The present observations are based on analysis of plankton and semi-plankton samples collected during August 2005, November 2008, February 2011 and April-May 2014 from all three districts, namely Cachar, Hailakandi and Karimganj of Barak valley (Fig. $1 \mathrm{~A}-\mathrm{C})$ of south Assam $\left(24^{\circ} 48^{\prime}-\right.$ $24.80^{\circ} \mathrm{N} ; 92^{\circ} 45^{\prime}-92.75^{\circ} \mathrm{E}$ ). The latter region is named after the Barak River which originates from the Barail Range (Assam-Nagaland border), flows through 40-50 km wide Barak valley and finally forms a part of the Surma-Meghna River system of Bangladesh. The study area is characterized by the tropical monsoon climate.

The plankton and semi-plankton samples were collected from scattered perennial floodplain lakes (beels), seasonal floodplain lakes (hoars) and small wetlands (dobas or dubies) by towing a nylobolt plankton net (\# size $50 \mu \mathrm{m}$ ) and were preserved in 5\% formalin. All the collections were screened with a Wild stereoscopic binocular microscope; the rotifers were isolated and mounted in polyvinyl alcohol-lactophenol, and were observed with Leica DM 1000 stereoscopic phase contrast microscope fitted with an image analyzer. Microphotographs were provided for interesting species and measurements were indicated in micrometers $(\mu \mathrm{m})$. Various rotifer taxa were identified following the works of Koste (1978), Koste \& Shiel (1987, 1989, 1990), Segers (1995), Sharma (1983, 1998), Sharma \& Sharma (1999, 2000, 2008, 2013), and Jersabek \& Leitner (2013). Segers (2007) and Jersabek \& Leitner (2013) were considered for biogeographic comments on various taxa.

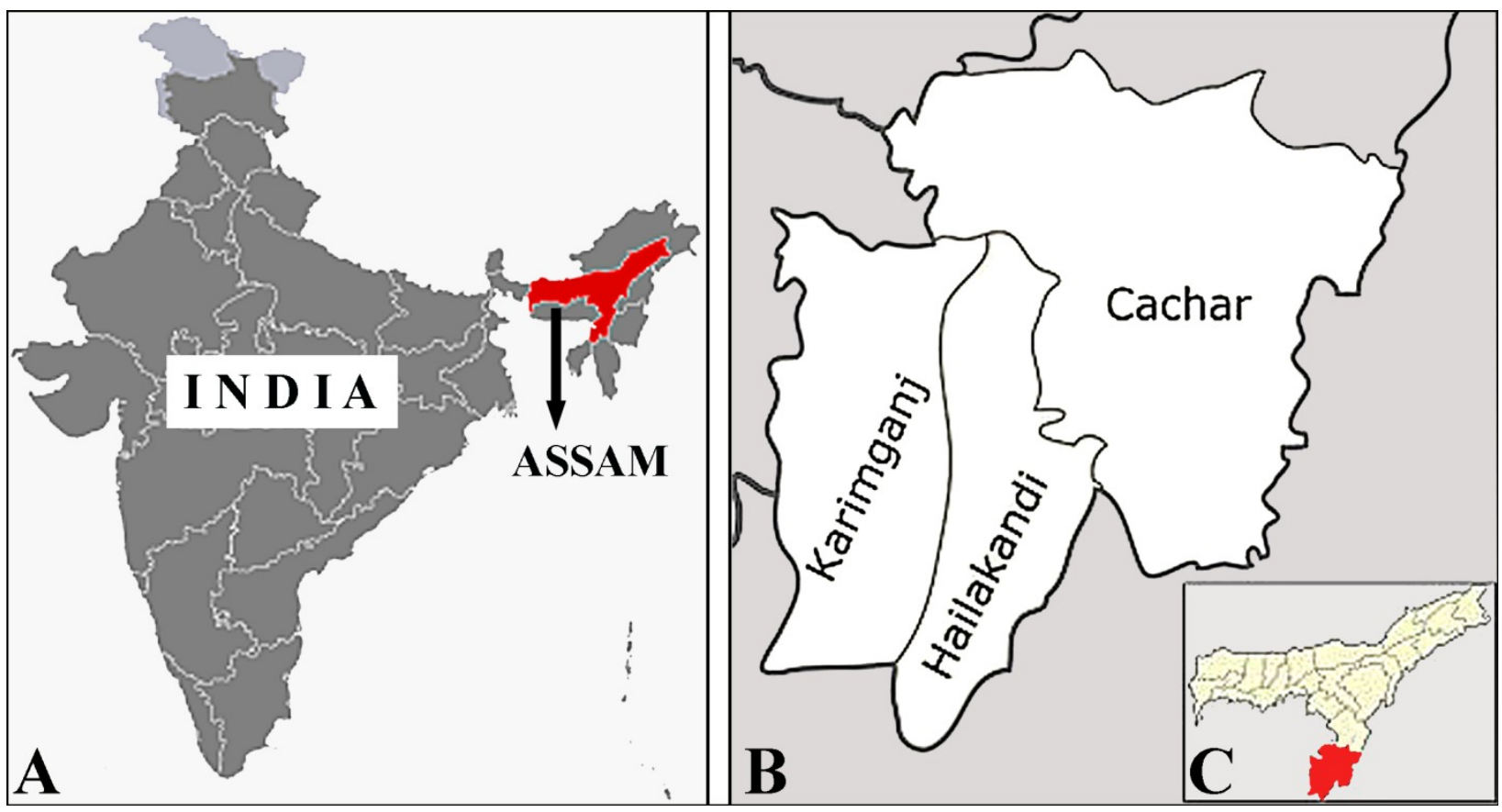

Figure 1. A = map of India indicating northeast India (NEI) and the state of Assam; B = map indicating the sampled districts of Barak valley of south Assam; $\mathrm{C}=$ inset map of Assam indicating Barak valley. 


\section{RESULTS}

Our plankton and semi-plankton collections from floodplains of the Barak valley of south Assam reveal 170 species, belonging to 39 genera and 19 families. The detailed systematic list of the examined species is presented below:

\section{Rotifera recorded from the Barak River floodplain wetlands}

\section{Phylum: Rotifera \\ Class: Eurotatoria \\ Subclass: Monogononta \\ Order: Ploima}

Family: Brachionidae

1. Anuraeopsis fissa Gosse, 1851

2. Brachionus angularis Gosse, 1851

3. B. bennini Leissling, 1924

4. B. bidentatus Anderson, 1889

5. B. budapestinensis Daday, 1885

6. B. calyciflorus Pallas, 1766

7. Brachionus caudatus Barrois \& Daday, 1894

8. B. diversicornis (Daday, 1883)

9. B. durgae Dhanapathi, 1974

10. B. falcatus Zacharias, 1898

11. B. forficula Wierzejski, 1891

12. B. mirabilis Daday, 1897

13. B. murphyi Sudzuki, $1989 * * \#$

14. B. nilsoni Ahlstrom, 1940*\#

15. B. quadridentatus Hermann, 1783

16. B. rubens Ehrenberg, 1838

17. B. srisumonae Segers, Kotethip \& Sanoamuang, 2004*\#

18. Keratella cochlearis (Gosse, 1851)

19. K. edmondsoni Ahlstrom, 1943

20. K. javana Hauer, $1937 \#$

21. K. lenzi Hauer, 1953

22. K. tecta (Gosse, 1851)

23. K. tropica (Apstein, 1907)

24. Platyias leloupi (Gillard, 1967)

25. P. quadricornis (Ehrenberg, 1832)

26. Plationus patulus (Muller, 1786)

Family: Epiphanidae

27. Epiphanes brachionus (Ehrenberg, 1837)

\section{Family: Euchlanidae}

28. Beauchampiella eudactylota (Gosse, 1886)

29. Dipleuchlanis propatula (Gosse, 1886)

30. Euchlanis dilatata Ehrenberg, 1832

31. E. incisa Carlin, 1939

32. E. triquetra Ehrenberg, 1838

33. Tripleuchlanis plicata (Levander, 1894)

Family: Mytilinidae

34. Lophocharis salpina (Ehrenberg, 1834)
35. Mytilina acanthophora Hauer, 1938

36. M. bisulcata (Lucks, 1912)

37. M. michelangellii Reid \& Turner, 1988

38. M. ventralis (Ehrenberg, 1830)

\section{Family: Trichotriidae}

39. Macrochaetus collinsi (Gosse, 1867)

40. M. longipes Myers, 1934

41. M. sericus (Thorpe, 1893)

42. T. tetractis (Ehrenberg, 1830)

43. Wolga spinifera (Western, 1894)

\section{Family: Lepadellidae}

44. Colurella adriatica Ehrenberg, 1831

45. C. colurus (Ehrenberg, 1830)

46. C. obtusa (Gosse, 1886)

47. C. sulcata (Stenroos, 1898)

48. C. uncinata (Müller, 1773)

49. Lepadella acuminata (Ehrenberg, 1834)

50. L. apsicora Myers, 1934

51. L. apsida Harring, 1916

52. L. benjamini Harring, 1916

53. L. biloba Hauer, 1958

54. L. costatoides Segers, 1992

55. L. dactyliseta (Stenroos, 1898)

56. L. discoidea Segers, 1993

57. L. ehrenbergi (Perty, 1850)

58. L. eurysterna Myers, 1942

59. L. heterostyla (Murray, 1913)

60. L. minuta (Weber \& Montet, 1918)

61. L. ovalis (Müller, 1786)

62. L. patella (Müller, 1773)

63. L. quinquecostata (Lucks, 1912)

64. L. rhomboides (Gosse, 1886)

65. L. triba Myers, 1934

66. L. triptera (Ehrenberg, 1832)

67. L. vandenbrandei Gillard, 1952\#

68. Squatinella lamellaris (Müller, 1786)

\section{Family: Lecanidae}

69. Lecane aculeata (Jakubski, 1912)

70. L. arcula Harring, 1914

71. L. batillifer (Murray, 1913)

72. L. bifastigata Hauer, 1938

73. L. bifurca (Bryce, 1892)

74. L. blachei Berzins, 1973

75. L. bulla (Gosse, 1851)

76. L. calcaria Harring \& Myers, $1926 * \#$

77. L. closterocerca (Schmarda, 1859)

78. L. crepida Harring, 1914

79. L. curvicornis (Murray, 1913)

80. L. decipiens (Murray, 1913)

81. L. dorysimilis Trinh Dang, Segers \& Sanoamuang, 2015\#

82. L. doryssa Harring, 1914

83. L. elegans Harring, 1914

84. L. flexilis (Gosse, 1886)

85. L. furcata (Murray, 1913)

86. L. haliclysta Harring \& Myers, 1926

87. L. hamata (Stokes, 1896) 
88. L. hastata (Murray, 1913)

89. L. hornemanni (Ehrenberg, 1834)

90. L. inermis (Bryce, 1892)

91. L. inopinata Harring \& Myers, 1926

92. L. lateralis Sharma, 1978

93. L. latissima Yamamoto, 1951\#

94. L. leontina (Turner, 1892)

95. L. ludwigii (Eckstein, 1883)

96. L. luna (Müller, 1776)

97. L. lunaris (Ehrenberg, 1832)

98. L. monostyla (Daday, 1897)

99. L. nitida (Murray, 1913)

100. L. niwati Segers, Kotethip \& Sanoamuang, 2004\#

101. L. obtusa (Murray, 1913)

102. L. papuana (Murray, 1913)

103. L. paxiana Hauer, 1940

104. L. ploenensis (Voigt, 1902)

105. L. pusilla Harring, 1914

106. L. pyriformis (Daday, 1905)

107. L. quadridentata (Ehrenberg, 1830)

108. L. rhenana Hauer, 1929\#

109. L. rhytida Harring \& Myers, 1926 \#

110. L. signifera (Jennings, 1896)

111. L. simonneae Segers, 1993

112. L. stichoclysta Segers, $1993^{* * \#}$

113. L. stenroosi (Meissner, 1908)

114. L. superaculeata Sanoamuang \& Segers, 1997\#

115. L. tensuiseta Harring, 1914

116. L. thienemanni (Hauer, 1938)

117. L. undulata Hauer, 1938

118. L. unguitata (Fadeev, 1925)

119. L. ungulata (Gosse, 1887)

\section{Family: Notommatidae}

120. Cephalodella gibba (Ehrenberg, 1830)

121. C. mucronata Myers, 1924

122. C. trigona (Rousselet, 1895) \#

123. Monommata longiseta (Müller, 1786)

124. M. maculata Harring \& Myers, 1930

125. Notommata pachyura (Gosse, 1886)

126. N. tripus Ehrenberg, 1838

\section{Family: Scaridiidae}

127. Scaridium longicaudum (Müller, 1786)

\section{Family: Gastropodidae}

128. Ascomorpha ecaudis Perty, 1850

129. A. ovalis (Bergendal, 1892)

\section{Family: Trichocercidae}

130. Trichocerca bicristata (Gosse, 1887)

131. T. bidens (Lucks, 1912) \#

132. T. capucina (Wierzejski \& Zacharias, 1893)

133. T. cylindrica (Imhof, 1891)

134. T. elongata (Gosse, 1886)

135. T. flagellata Hauer, 1937

136. T. hollaerti De Smet, 1990\#

137. T. insignis (Herrick, 1885) \#
138. T. longiseta (Schrank, 1802)

139. T. pusilla (Jennings, 1903)

140. T. rattus (Müller, 1776)

141. T. similis (Wierzejski, 1893)

142. T. tenuior (Gosse, 1886)

143. T. tigris (Muller, 1786)

144. T. weberi (Jennings, 1903)

Family: Asplanchnidae

145. Asplanchna brightwellii Gosse, 1850

146. A. priodonta Gosse, 1850

Family: Synchaetidae

147. Ploesoma lenticulare Herrick, 1885

148. Polyarthra vulgaris Carlin, 1943

\section{Family: Dicranophoridae}

149. Dicranophoroides caudatus (Ehrenberg, 1834)

150. Dicranophorus forcipatus (Müller, 1786)

Order: Flosculariaceae

Family: Flosculariidae

151. Sinantherina socialis (Linne, 1758)

152. S. spinosa (Thorpe, 1893)

Family: Conochilidae

153. Conochilus unicornis Rousselet, 1892

Family: Hexarthridae

154. Hexarthra mira (Hudson, 1871)

Family: Testudinellidae

155. Testudinella amphora Hauer, 1938\#

156. T. brevicaudata Yamamoto, 1951\#

157. T. dendradena de Beauchamp, 1955\#

158. T. emarginula (Stenroos, 1898)

159. T. greeni Koste, 1981\#

160. T. parva (Ternetz, 1892)

T. parva bidentata $($ Ternetz, 1892)

161. T. patina (Hermann, 1783)

162. T. tridentata Smirnov, 1931\#

163. Pompholyx sulcata Hudson, 1885

Family: Trochosphaeridae

164. Filinia camasecla Myers, 1938

165. F. longiseta (Ehrenberg, 1834)

166. F. opoliensis (Zacharias, 1898)

167. F. saltator (Gosse, 1886)

168. Trochosphaera aequatorialis Semper, 1872

Sub-class: Bdelloidea

Order: Philodinida

Family: Philodinidae

169. Dissotrocha aculeata (Ehrenberg, 1832)

170. Rotaria neptunia (Ehrenberg, 1830)

* New records from the Indian sub-region; ** new records from Assam state; \# reported only from NEI 
Brachionus srisumonae (Fig. 2), B. nilsoni (Fig. 3 ) and Lecane calcaria (Fig. 4) are new records from the Indian sub-region, while Brachionus murphyi (Fig. 5) and Lecane stichoclysta (Fig. 6) are new records from Assam state. Several other species of biogeographic interest noticed in our collections include Brachionus bennini (Fig. 7), $B$. durgae (Fig. 8), Filinia camasecla (Fig. 9), Keratella edmondsoni (Fig. 10), Lecane batillifer (Fig. 11), L. bifastigata (Fig. 12), L. blachei (Fig. 13), L. dorysimilis (Fig.14), L. latissima (Fig.15), L. niwati (Fig.16), L. rhenana (Fig.17), L. rhytida (Fig. 18), L. simonneae (Fig. 19), L. superaculeata (Fig. 20), Lepadella benjamini (Fig. 21), L. discoidea (Fig. 22), L quinquecostata (Fig. 23), L. vandenbrandei (Fig. 24), Testudinella amphora (Fig. 25), T. brevicaudata (Fig. 26), T. greeni (Fig. 27), T. parva bidentata (Fig. 28), T. tridentata (Fig. 29) and Trichocerca hollaerti (Fig. 30).

Lecanidae, Brachionidae, Lepadellidae, Trichocercidae and Testudinellidae are represented by 50 , 26, 25, 15 and 10 species, respectively; Notommatidae and Euchlanidae include 7 and 6 species respectively; and Mytilinidae, Trichocercidae and Trochosphaeridae include five species each. Lecane, Lepadella, Brachionus, Trichocerca, Testudinella and Keratella record 50, 19, 16, 16, 9 and 6 species, respectively. Our 2005, 2008, 2011 and 2014 collections indicate 153,148, 155 and 150 species, respectively.

\section{DISCUSSION}

Our collections from the floodplain wetlands of Barak valley of Assam state of NEI reveal rich Rotifera diversity of 170 species belonging to 39 genera and 19 families. The richness forms a notable fraction i.e., $\sim 70 \%, \sim 57 \%$ and $\sim 39 \%$ of the species of the phylum known till date from Assam, NEI and India (Sharma \& Sharma 2017, BKS unpublished), respectively; the rich and diverse rotifer assemblages are hypothesized to microhabitat and ecological heterogeneity of the sampled wetlands. The reports of $\sim 90 \%, \sim 87 \%, \sim 91 \%$ and $\sim 82 \%$ of species from our $2005,2008,2012$ and 2014 surveys from the Barak basin endorse consistently biodiverse rotifers with limited seasonal differences in species composition vis- $a$ vis the sampling intensity. This study marks a significant update over our unpublished report of 90 species from Barak valley (Sharma \& Sharma 2014a). Our collections from south Assam even reveal more species-rich rotifers than the reports of 162, 161 and 150 species from the states of Mizoram (Sharma \& Sharma 2015), Meghalaya (Sharma et al. 2016) and Nagaland (Sharma et al. 2017) of NEI, respectively.

The present study indicates higher rotifer richness than certain reports from the floodplains of the Rio Pilcomayo National Park of Argentina (114 species; Jose de Paggi 2001), 124 and 136 species from Oguta and Iyi-Efi lakes of the Niger delta (Segers et al. 1993) of Africa, respectively; Lake Guarana (130 species; Bonecker et al. 1994), and Rio Tapajos (151 species; Koste 1974) and Lago Camaleao (148 species; Koste \& Robertson 1983) of Brazil, respectively; Thale-Noi Lake, Thailand (106 taxa; Segers \& Pholpunthin 1997); and Laguana Bufeos of Bolivia (104 species; Segers et al. 1998). The richness from the Barak River floodplains, however, compares well with 184 species known from more intensively sampled Upper Paraná floodplains (Bonecker et al. 1994, 1998, 2005) of Brazil. Further, our collections highlight more biodiverse rotifer assemblages than the 144 species reported from beels of the Majuli River Island (Sharma et al. 2015) and 141 species from three beels of the Dibru-Saikhowa Biosphere Reserve (Sharma et al. 2017) of upper Assam; 164 species from 15 beels (Sharma 2005) and 160 species from four beels of lower Assam (Sharma et al. 2018); 162 species from Loktak Lake basin of Manipur (Sharma et al. 2016); and 110 species from the floodplains of the Yamuna River at Delhi (Arora \& Mehra 2003). The stated comparisons affirm the rich faunal diversity of the floodplain wetlands of the Barak River and thus endorse our reports from the floodplains of NEI (Sharma \& Sharma 2014a, 2014b, 2017, 2018a, Sharma et al. 2018) vis-a-vis Rotifera-rich habitats. In contrast, comparisons with reports of 12 (Kar \& Kar 2013), 2 (Gupta \& Devi 2014), 7 (Narzary et al. 2015), 18 (Das \& Kar 2016), 20 (Kar \& Kar 2016a), 20 (Kar \& Kar 2016b), 21 (Das et al. 2018) and 10 (Kar et 


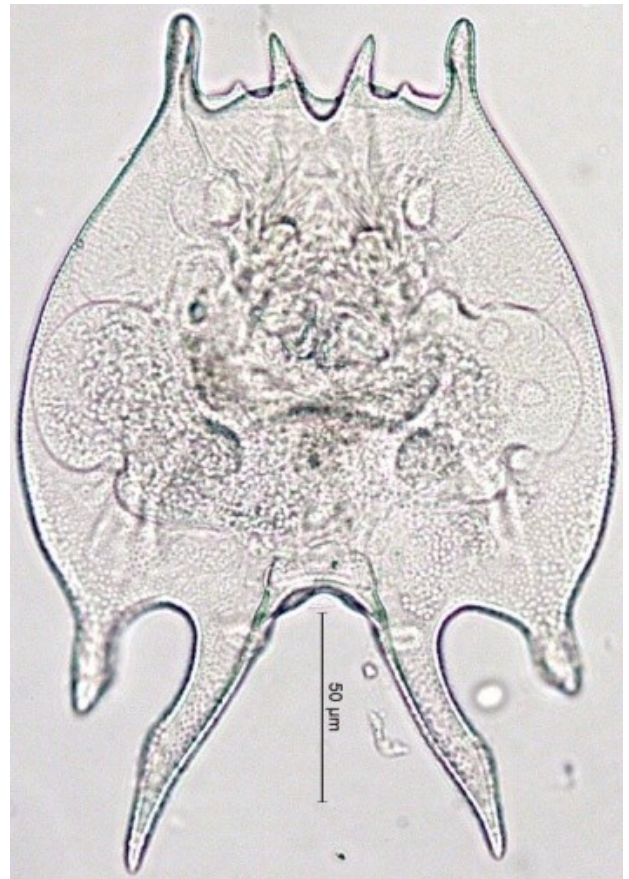

2

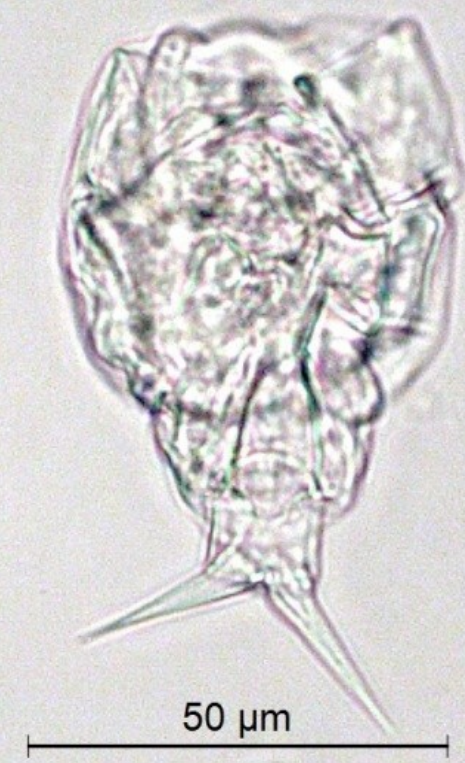

4

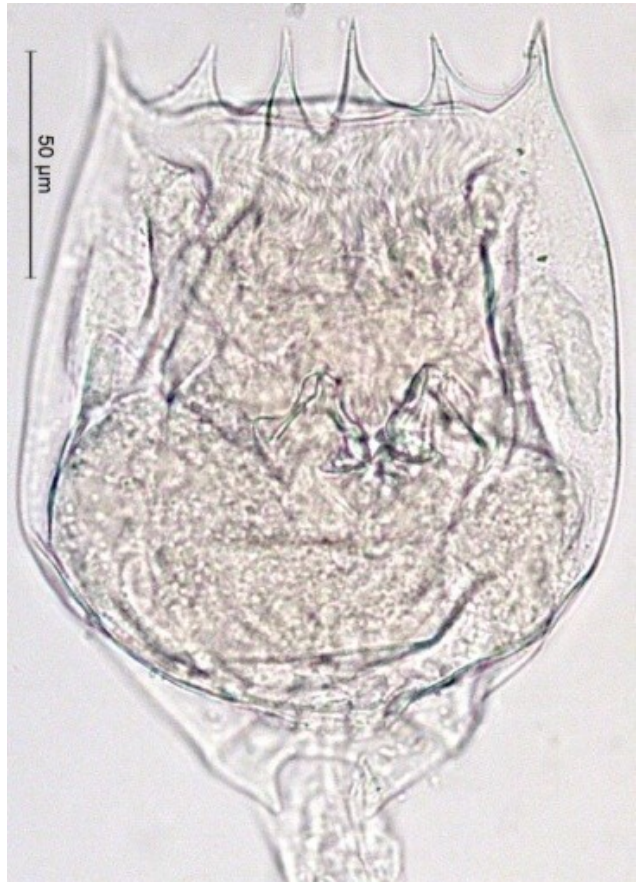

3

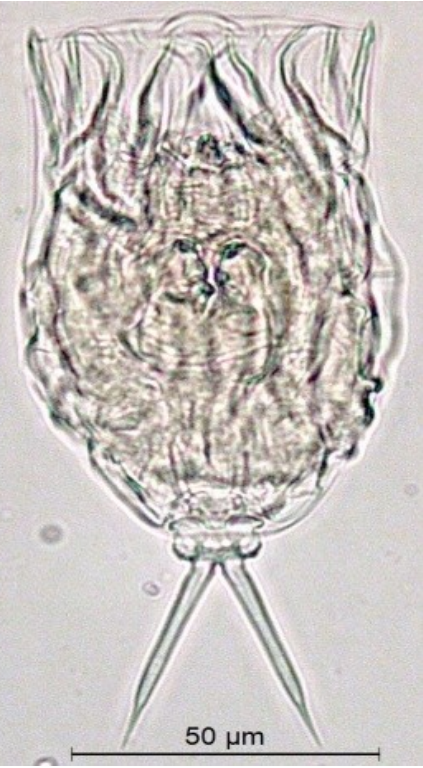

6

Figures 2-6. New records of Rotifera from Barak valley. 2 = Brachionus srisumonae Segers, Kotethip \& Sanoamuang (dorsal view); 3 = Brachionus nilsoni Ahlstrom (ventral view); 4 = Lecane calcaria Harring \& Myers (ventral view); 5 = Brachionus murphyi Sudzuki (ventral view); 6 = Lecane stichoclysta Segers (ventral view). 


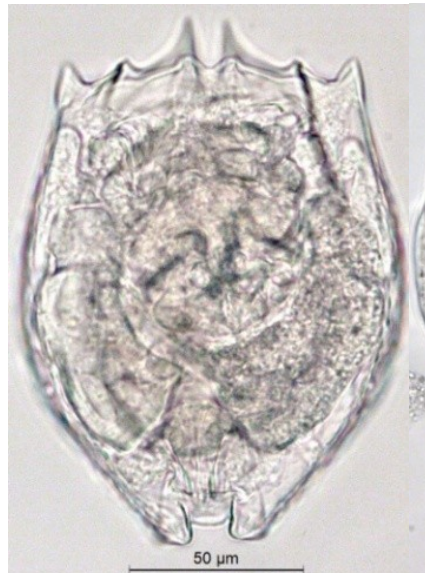

7

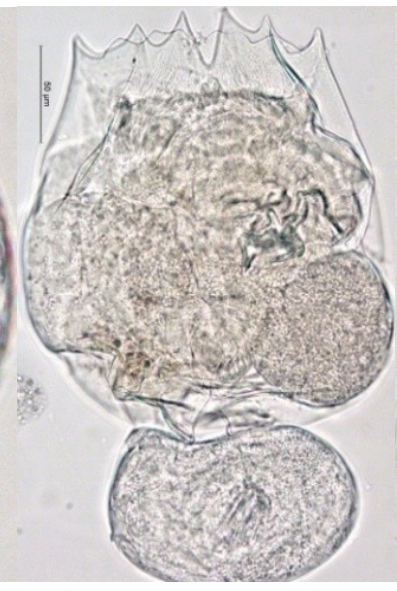

8

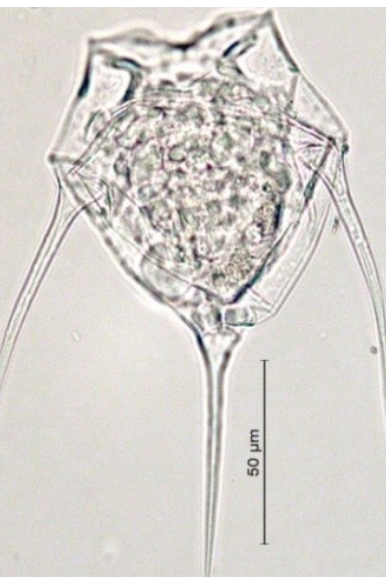

9

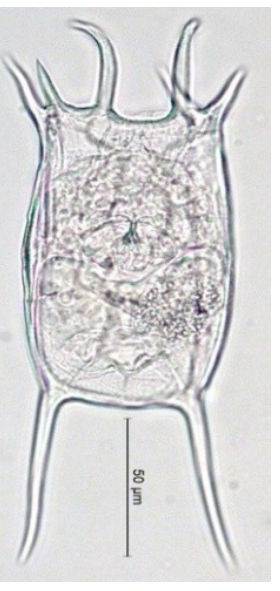

10

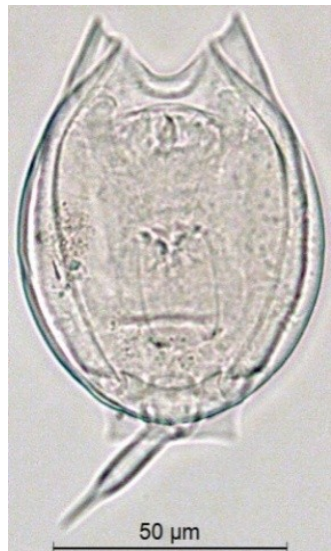

11

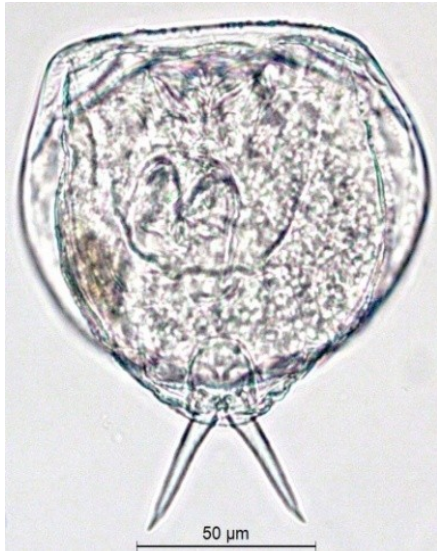

15

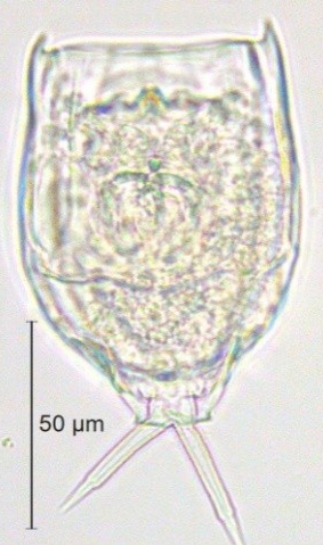

12

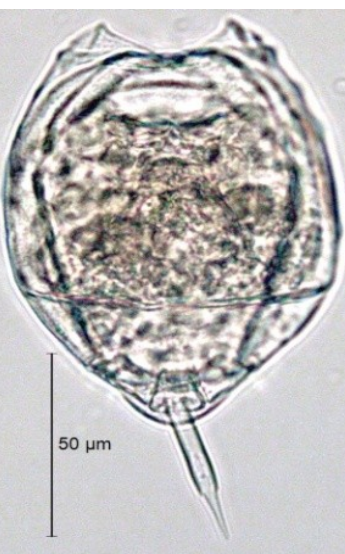

16

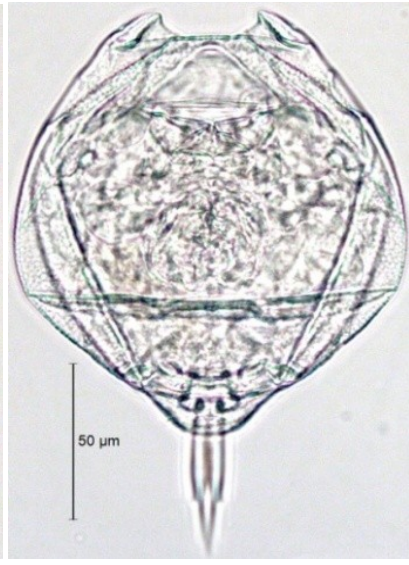

13

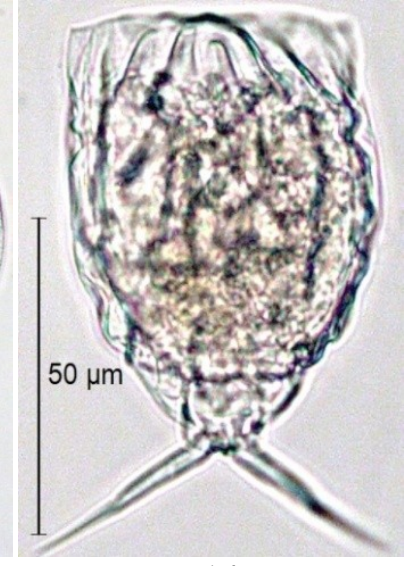

14

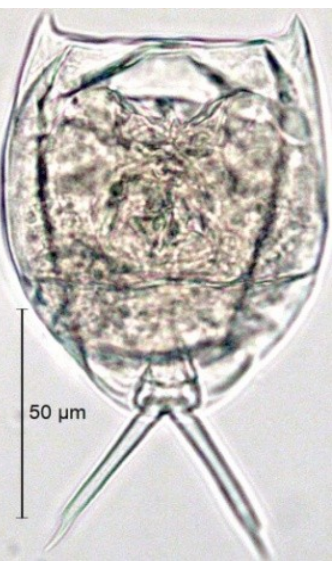

17

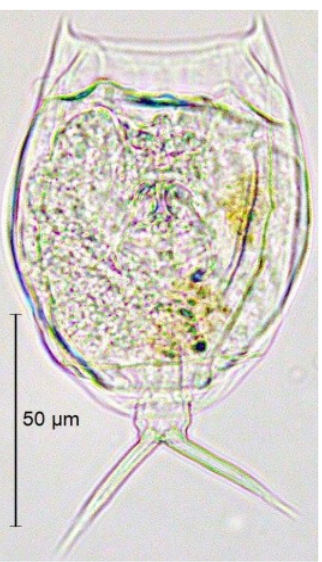

18

Figures 7-18. Interesting Rotifera from Barak valley. 7 = Brachionus bennini Leissling (ventral view); $8=$ Brachionus durgae Dhanapathi (dorsal view); 9 = Filinia camasecla Myers (ventral view); $10=$ Keratella edmondsoni Ahlstrom (ventral view); 11 = Lecane batillifer (Murray) (dorsal view); 12 = Lecane bifastigata Hauer (ventral view); 13 = Lecane blachei Berzins (ventral view); 14 = Lecane dorysimilis Trinh Dang, Segers \& Sanoamuang (dorsal view); 15 = Lecane latissima Yammoto (dorsal view); 16 = Lecane niwati Segers, Kotethip \& Sanoamuang (ventral view); $17=$ Lecane rhenana Hauer (ventral view); 18 = Lecane rhytida Harring \& Myers (dorsal view). 


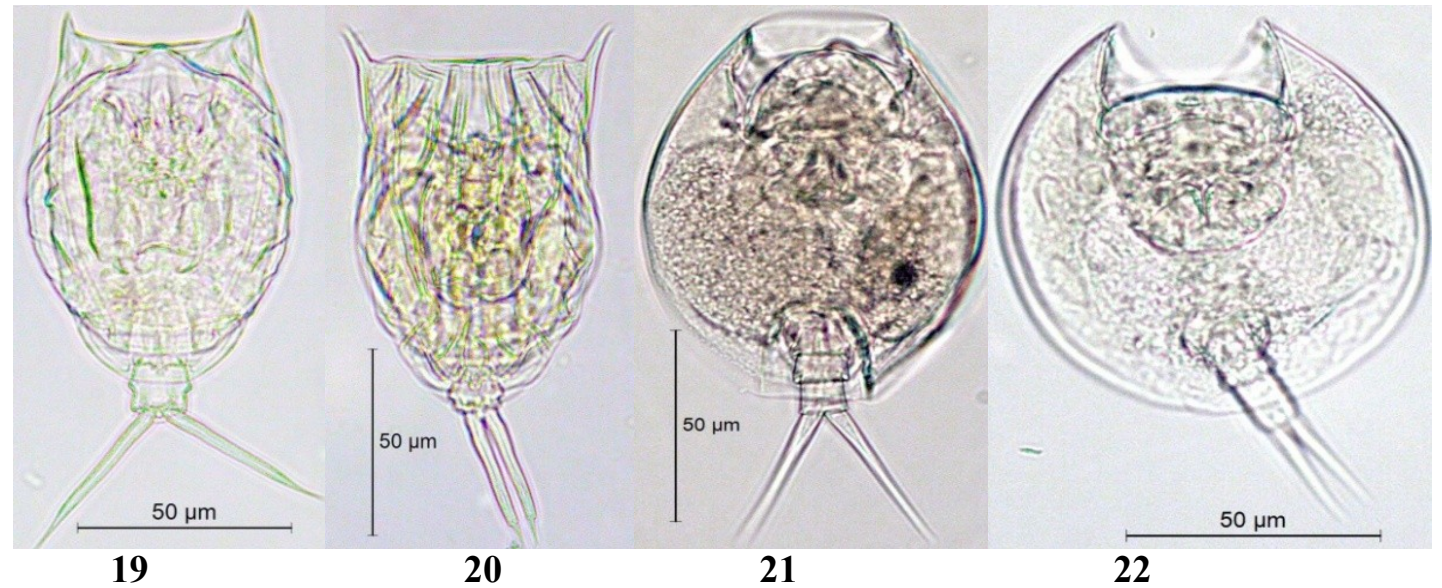

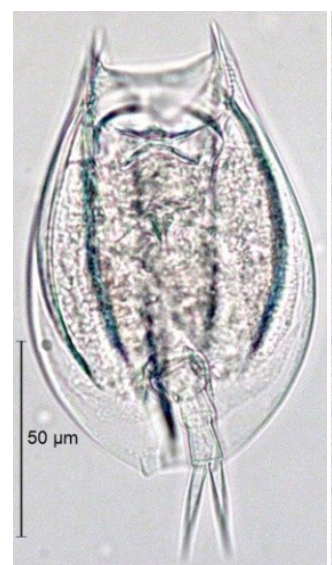

23

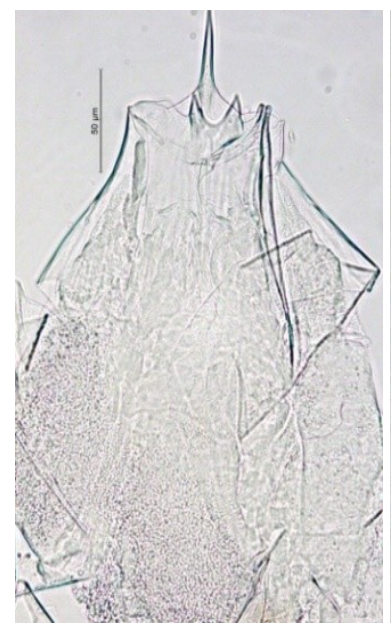

27

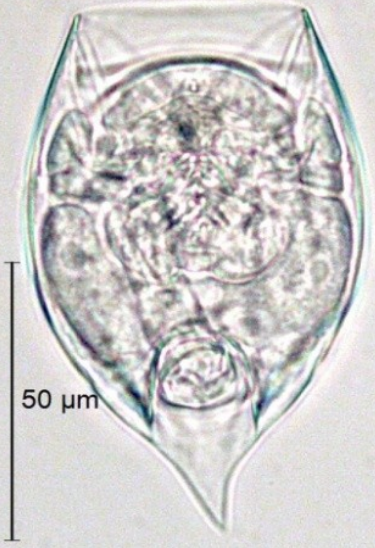

24

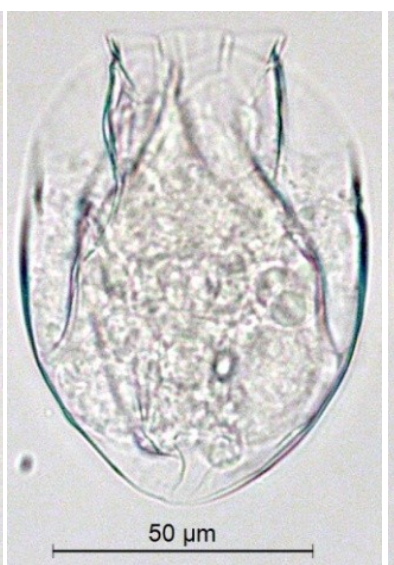

25

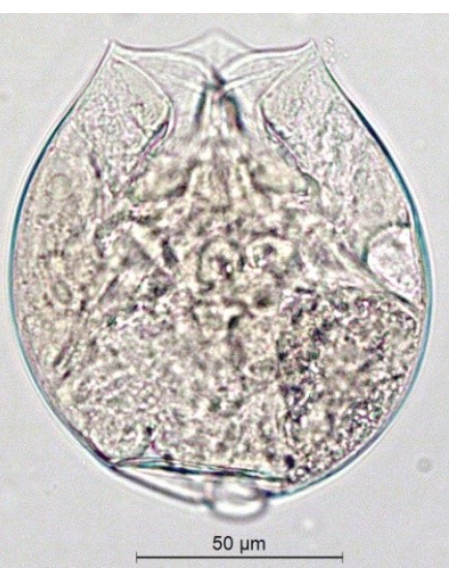

26

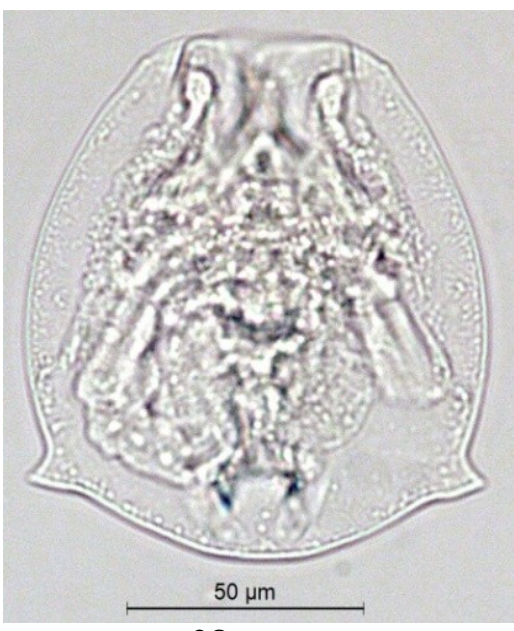

28

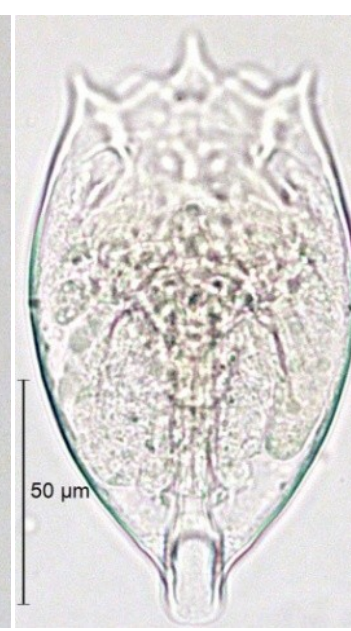

29

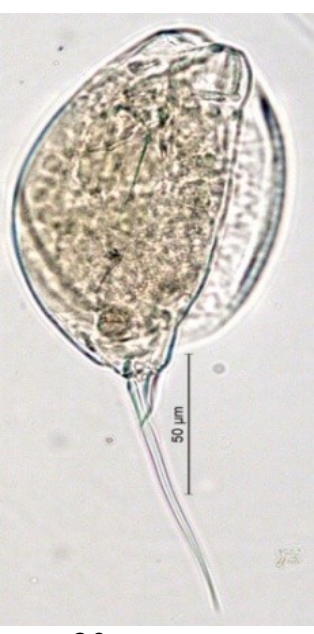

30

Figures 19-30. Interesting Rotifera species from Barak valley. $19=$ Lecane simonneae Segers (dorsal view); 20 = Lecane superaculeata Sanoamuang \& Segers (ventral view); 21 = Lepadella benjamini Harring (ventral view); $22=$ Lepadella discoidea Segers (ventral view); 23 = Lepadella quinquecostata (Lucks) (dorsal view); 24 = Lepadella vandenbrandei Gillard (ventral view) 25 = Testudinella amphora Hauer (dorsal view); 26 = Testudinella brevicaudata Yamamoto (ventral view); 27 = Testudinella greeni (part) (ventral view); 28 = Testudinella parva bidentata (Ternetz) (ventral view); $29=$ Testudinella tridentata Smirnov (ventral view); $30=$ Trichocerca hollaerti De Smet (lateral view). 
al. 2018) rotifer taxa from wetlands of south Assam indicate under-estimation of the richness with lack of species identifications in most of these works.

Brachionus srisumonae, B. nilsoni and Lecane calcaria are new additions to Rotifera of the Indian sub-region; these species are listed elsewhere from the Oriental region from Thailand (Sa-Ardrit et al. 2013). Of these, the rare and interesting brachionid $B$. srisumonae was described from Thailand (Segers et al. 2004) and was since listed as 'Thai endemic' (Sa-Ardrit et al. 2013), while we now designate it as 'Oriental endemic'. The cosmopolitan $B$. nilsoni is likely to be confused with $B$. urceolaris while $L$. calcaria, known from the Neotropical and Oriental regions (Segers 2007), is characterized by its small-size, soft lorica and distinctive toes. All three new records are notable for rare occurrence in our collections from Barak valley. In addition, Brachionus murphyi and Lecane stichoclysta are new records from Assam state; the former was reported from India from Nagaland (Sharma et al. 2017) state of NEI while this brachionid and Lecane stichoclysta are recently observed from Arunachal Pradesh, the eastern Himalayas (Sharma and Sharma, 2019).

Our results highlight both (i) the global and (ii) regional distribution importance of the rotifers from Barak valley. The former feature is endorsed by a notable fraction $(\sim 15 \%)$ of the reported species including: (a) the Australasian Lecane batillifer; (b) the Oriental endemics Brachionus srisumonae, B. murphyi, Keratella edmondsoni, Lecane blachei, L. latissima, L. niwati, L. superaculeata and Filinia camasecla; (c) the Paleotropical Keratella javana, Lecane lateralis, L. simonneae, L. stichoclysta, L. unguitata, Lepadella discoidea, L. vandenbrandei, Testudinella brevicaudata, T. greeni and Trichocerca hollaerti; (d) the Indo-Chinese L. dorysimilis; (e) the cosmo (sub) tropical Brachionus durgae; and (f) other species namely Cephalodella trigona, L. bifastigata, L. calcaria, and Testudinella amphora. Besides, we report a sizable component $(\sim 37 \%)$ of species of (ii) regional distribution interest for India with $\sim 13 \%$ known exclusively to date from
NEI; the latter include Brachionus murphyi, $B$. nilsoni, B. srisumonae, Cephalodella trigona, Keratella javana, Lecane calcaria, L. dorysimilis, L. latissima, L. niwati, L. rhenana, L. rhytida, L. stichoclysta, L. superaculeata, Lepadella vandenbrandei, Testudinella amphora, T. brevicaudata, T. dendradena, T. greeni, T. tridentata, Trichocerca bidens, $T$. hollaerti and $T$. insignis.

Lecanidae, represented by the 'tropic-centered' Lecane, records distinctly diverse nature (50 species; $30 \%$ ). The lecanids along with Eurotatoria families Brachionidae $\approx$ Lepadellidae $(\sim 32 \%)$ largely contribute to the rotifer richness of the Barak floodplains; Trichocercidae $>$ Testudinellidae are notable $(\sim 15 \%)$, while Notommatidae, Euchlanidae, Mytilinidae, Trichotriidae and Trochosphaeridae collectively include $16.5 \%$ species. Besides the speciose genus Lecane, Lepadella $>$ Brachionus $=$ Trichocerca together include $\sim 32 \%$ species, while Testudinella > Keratella deserve mention ( $\sim 9 \%)$. The richness of the 'tropic-centered' Brachionus (16 species) in the Barak valley floodplains is higher than our reports from other floodplains of NEI i.e., the Majuli River Island (Sharma 2014) and the Dibru-Saikhowa Biosphere reserve (Sharma et al. 2017) of upper Assam, and the Loktak Lake basin of Manipur (Sharma \& Sharma 2018a). The richness importance of Lecane and Brachionus, large fraction of cosmopolitan species $(\sim 66 \%)$ and occurrence of several pantropical and cosmotropical species ( 20\%) imparts 'tropical character' to the rotifer assemblages of the Barak valley floodplains. This generalization concurs with various global reports on the composition of the tropical rotifer faunas (Fernando 1980; Dussart et al. 1984; Segers 1996, 2001, 2008). The lecanid dominance compares well with the reports from the floodplains of Africa (Segers et al. 1993, 1998), Thailand (Sa-Ardrit et al. 2013) and Argentina (Jose de Paggi 2001). The overall significance of important Eurotatoria families and genera concurs with the reports from the floodplains of Africa (Segers et al. 1993, Green 2003), Brazil (Koste 1974, Koste \& Robertson 1983, Bonecker et al. 1998), Thailand (Segers \& Pholpunthin 1997), Bolivia (Segers et al. 1998) and Argentina (Jose De 
Paggi 2001). This generalization, in turn, assigns the littoral-periphytonic nature to Rotifera of the Barak River floodplains with occurrence of several small-sized species of Colurella, Lecane, Lepadella and Trichocerca. The latter attribute is hypothesized to the predation influence of juvenile fish and invertebrates (Baumgartner et al. 1997); this feature also endorses our remarks on the rotifers from the floodplains of NEI (Sharma \& Sharma 2014a, 2018a; Sharma et al. 2016, 2017, 2018) as well as of the Kashmir Himalayas (Sharma \& Sharma 2018b).

To sum up, this first comprehensive analysis of zooplankton of the Barak River floodplains of south Assam depicts the species-rich and diverse Rotifera assemblages, and thus affirms microhabitat and environmental heterogeneity of the wetlands of the region. Our study highlights sizeable fractions of species of global as well as regional biogeographic interest, various new records and interesting taxa, the littoral-periphytic nature, several small-sized species, large fraction of cosmopolitan species and occurrence of several pantropical and cosmotropical rotifers. The results merit biodiversity and biogeographic interest for Indian Rotifera as well as that of the floodplains of the Indian sub-region in particular. Analysis of more intensive collections with emphasis on the periphytic, sessile, colonial and benthic taxa is likely to update the rotifer biodiversity of the Barak floodplains, Assam state and NEI.

Acknowledgements - The senior author (BKS) is thankful to the Ministry of Environment \& Forests (Govt. of India) for a research project No. 22018-09/2010-CS (Tax) which facilitated the sampling partially, while this study was initiated under the "University with Potential for Excellence Program (Focused Area: Biosciences)" of North-Eastern Hill University, Shillong. We thank Drs. L. Pachuau and M. K. Hatimuria for help in the field collections. The authors have no conflict of interests.

\section{REFERENCES}

ANDERSON, H.H. (1889): Notes on Indian Rotifera. Journal of the Asiatic Society of Bengal, 58: 45-58.

ARORA, J. \& MEHRA, N.K. (2003): Species diversity of planktonic and epiphytic rotifers in the backwaters of the Delhi segment of the Yamuna River, with remarks on new records from India. Zoological Studies, 42(2): 239-247.

Baumgartner, G., NaKataki, K.M., CAVicchiolo, M. \& BAUGARTNER, M.S. (1997): Some aspects of the ecology of fish larvae in the floodplain of the high Parana River. Review Brazilian Zoology, 14: 551-563.

Bonecker, C.C., Costa, C.L.D., Velho, L.F.M. \& LANSAC-TÔHA, F.A. (2005): Diversity and abundance of the planktonic rotifers in different environments of the Upper Paraná River floodplain (Paraná State - Mato Grosso do Sul State, Brazil). Hydrobiologia, 546: 405-414.

doi: $10.1007 / \mathrm{s} 10750-005-4283-2$

Bonecker, C.C., LANSAC-TÔHA, F.A. \& RossA, D.C. (1998): Planktonic and non-planktonic rotifers in two environments of the upper Parana River floodplain, state of Mato Grosso do Sul, Brazil. Brazilian Archives of Biology \& Technology, 41: 447-456. doi: 10.1590/S1516-89131998000400009

Bonecker, C.C., LANSAC-TÔHA, F.A. \& Staub, A. (1994): Qualitative study of Rotifers in different environments of the high Parana River floodplain (MS), Brazil. Revista UNIMAR, 16: 1-16.

DAS, P. \& KAR, D. (2016): Composition, abundance and diversity of zooplankton population from three different wetlands from Barak valley, Assam. International Journal of Applied \& Natural Sciences, 5(5): 41-46.

Das, U., Das, P., Kar, S., Chitra, J. \& Kar, D. (2018): An assessment on zooplankton diversity between three freshwater habitats of Barak valley, Assam. Uttar Pradesh Journal of Zoology, 38(1): 26-34.

DusSART, B.H., FERNANDO, C.H., MATSUMURATUNDISI, J. \& SHIEL, R.J. (1984): A review of systematics, distribution and ecology of tropical freshwater zooplankton. Hydrobiologia, 113: 77-91. doi: 10.1007/BF00026594

FERNANDO, C.H. (1980): The freshwater zooplankton of Sri Lanka, with a discussion of tropical freshwater zooplankton composition. International Review of Hydrobiology, 65: 411-426. doi: 10.1002/iroh.19800650310

GREEN, J. (2003): Associations of planktonic and periphytic rotifers in a tropical swamp, the Okavango Delta, Southern Africa. Hydrobiologia, 490: 197209. doi: $10.1023 / \mathrm{A}: 1023475217987$ 
GuPTA, S. \& DEVI, S.S. (2014): Ecology of Baskandi anua, an oxbow lake of south Assan, North East India. Journal of Environmental Biology, 35: 11011105 .

JERSABEK, C.D \& LEITNER, M.F. (2013): The Rotifer World Catalog. World Wide Web electronic publication. http://www.rotifera.hausdernatur.at/, accessed $\{20.09 .2018\}$.

José DE PAGGI, S. (2001): Diversity of Rotifera (Monogononta) in wetlands of Rio Pilcomayo national park, Ramsar site (Formosa, Argentina). Hydrobiologia, 462: 25-34.

doi: $\underline{10.1023 / \mathrm{A}: 1013157914860}$

KAR, S. \& KAR, D. (2013): Studies on zooplankton diversity of an Oxbow Lake of South Assam, India. International Journal of Current Research, 5 (12): 3317-3322.

KAR, S. \& KAR, D. (2016a): Zooplankton diversity in a freshwater lake of Cachar, Assam. International Journal of Applied Biology, Pharmaceutics \& Technology, 7(1): 301-305.

KAR, S. \& KAR, D. (2016b): Zooplankton diversity of a freshwater wetland of Assam. International Journal of Biological Research, 7(2): 614-620.

KAR, S., DAS, P., DAS, U., BimOlA, M., KaR, D. \& ADITYA, G. (2018): Correspondence of zooplankton assemblage and water quality in wetlands of Cachar, Assam, India: Implications for environmental management. Limnology Review, 18 (1): 9-19. doi: $10.2478 /$ limre-2018-0002

Koste, W. (1974): Zur Kenntnis der Rotatorienfauna der 'schwimmenden Weise' einer Uferlagune in der Varzea Amazoniens, Brasilien. Amazoniana, 5: 2560.

Koste, W. (1978): Rotatoria. Die Rädertiere Mitteleuropas, begründet von Max Voigt. Überordnung Monogononta. Gebrüder Borntraeger, Berlin, Stuttgart. I. 673 pp., II. Tafelband. 234 pp.

Koste, W. \& Robertson, B. (1983): Taxonomic studies of the Rotifera (Phylum Aschelminthes) from a central Amazonian varzea lake, Lago Camaleao (Ilha de Marchantaria, Rio Solimoes, Amazonas, Brazil). Amazoniana, 7(2): 225-254.

Koste, W. \& SHIEL, R.J. (1987): Rotifera from Australian inland waters. II. Epiphanidae and Brachionidae (Rotifera, Monogononta). Invertebrate Systenatics, 7: 949-1021. doi: 10.1071/IT9870949
Koste, W. \& SHIEL, R.J. (1989): Rotifera from Australian inland waters. IV. Colurellidae (Rotifera, Monogononta). Transactions of the Royal Society of South Australia, 113: 119-143.

Koste, W. \& SHIEL, R.J. (1990): Rotifera from Australian inland waters. V. Lecanidae (Rotifera, Monogononta). Transactions of the Royal Society of South Australia, 114: 1-36.

MANI, M.S. (1974): Biogeographical evolution in India. In. MANI, M.S. (Ed.) Ecology and Biogeography in India. Dr. W. Junk b. v. Publishers, The Hague, p. 698-724.

NARZARY, A., DAS, S., DAS, B.K., Romen Singh, N., KAR, S., DAS, P., DutTA, B. \& KAR, D. (2015): A preliminary study on zooplankton diversity of Ramnagar Anua, Srikona Beel and Tapang Haor of Cachar district, Assam, India: A Project Report. Journal of Chemistry, Biology \& Physical Sciences, Section B. 5(3): 2809-2817.

RANGA REDDY, Y. (2013): Neodiaptomus prateek n. sp., a new freshwater copepod from Assam, India, with critical review of generic assignment of Neodiaptomus spp. and a note on diaptomid species richness (Calanoida: Diaptomidae). Journal of Crustacean Biology, 33(6): 849-865. doi: $\underline{10.1163 / 1937240 X-00002195}$

SA-ARDRIT, P., PhOLPUNThIN, P. \& SEgERS, H. (2013): A checklist of the freshwater rotifer fauna of Thailand (Rotifera, Monogononta, Bdelloidea). Journal of Limnology, 72(2): 361-375. doi: $10.4081 /$ jlimnol.2013.s2.e18

SEGERS, H. (1995): Rotifera 2: Lecanidae. In. DUMONT, H.J. \& NogRADY, T. (Eds.) Guides to identification of the Microinvertebrates of the Continental waters of the world. VI, SPB Academic Publishing bv. Amsterdam, the Netherlands, $226 \mathrm{pp}$.

SEGERS, H. (1996): The biogeography of littoral Lecane Rotifera. Hydrobiologia, 323: 169-197. doi: 10.1007/BF00007845

SEGERS, H. (2013): A biogeographical analysis of rotifers of the genus Trichocerca Lamarck, 1801 (Trichocercidae, Monogononta, Rotifera), with notes on taxonomy. Hydrobiologia, 500: 103-114. doi: 10.1007/978-94-007-1084-9_7

SEGERS, H. (2007): Annotated checklist of the rotifers (Phylum Rotifera), with notes on nomenclature, taxonomy and distribution. Zootaxa, 1564: 1-104. doi: $\underline{10.11646 / \text { zootaxa.1564.1.1 }}$ 
SEGERS, H. (2008): Global diversity of rotifers (Rotifera) in freshwater. Hydrobiologia, 595: 49-59. doi: 10.1007/s10750-007-9003-7

Segers, H., Ferrufino, N.L. \& De MeEster, L. (1998): Diversity and zoogeography of Rotifera (Monogononta) in a flood plain lake of the Ichilo River, Bolivia, with notes on little known species. International Review of Hydrobiology, 83: 439-448. doi: 10.1002/iroh.19980830512

SEgERs, H., Nwadiaro, C.S. \& Dumont, H.J. (1993): Rotifera of some lakes in the floodplain of the river Niger (Imo State, Nigeria). II. Faunal composition and diversity. Hydrobiologia, 250: 63-71. doi: $\underline{10.1007 / \mathrm{BF} 00007495}$

Segers, H. \& Pholpunthin, P. (1997): New and rare Rotifera from Thale Noi Lake, Pattalang Province, Thailand, with a note on the taxonomy of Cephalodella (Notommatidae). Annales de Limnologie, 33: 13-21. doi: 10.1051/limn/1997001

Segers, H., KotethiP, W. \& SANOAMUANG, L. (2004): Biodiversity of freshwater microfauna in the floodplain of the River Mun, Northeast Thailand: The Rotifera Monogononta. Hydrobiologia, 515: 1-9. doi: 10.1023/B:HYDR.0000027299.17844.61

SHARMA, B.K. (1983): The Indian species of the genus Brachionus (Eurotatoria: Monogononta: Brachionidae). Hydrobiologia, 104: 31-39. doi: 10.1007/BF00045949

SHARMA, B.K. (1998): Freshwater rotifers (Rotifera: Eurotatoria). State Fauna Series: Fauna of West Bengal, Zoological Survey of India, Calcutta, 3(11): 341-461.

SHARMA, B.K. (2005): Rotifer communities of floodplain lakes of the Brahmaputra basin of lower Assam (N. E. India): biodiversity, distribution and ecology. Hydrobiologia, 533: 209-221. doi: 10.1007/s10750004-2489-3

SHARMA, B.K. (2014): Rotifers (Rotifera: Eurotatoria) from wetlands of Majuli - the largest river island, the Brahmaputra river basin of upper Assam, northeast India. Check List, 10(2): 292-298. doi: 10.15560/10.2.292

Sharma, B.K., HAOKIP, T.P \& Sharma, S. (2016): Loktak Lake, Manipur, northeast India: a Ramsar site with rich rotifer (Rotifera: Eurotatoria) diversity and its meta-analysis. International Journal of Aquatic Biology, 4(2): 69-79.

SHARMA, B.K., KHAN, S.I. \& SHARMA, S. (2018): Biodiverse rotifer assemblage (Rotifera: Eurotatoria) of floodplain lakes of the Brahmaputra basin of lower Assam, northeast India: composition and ecosystem diversity. Journal of Oceanology and Limnology, 36(2): 362-375. doi: 10.1007/s00343-0176251-x

Sharma, B.K., NoroH, N. \& Sharma, S. (2017): Rotifers (Rotifera: Eurotatoria) from floodplain lakes of the Dibru Saikhowa Biosphere Reserve, upper Assam, northeast India: ecosystem diversity and biogeography. International Journal of Aquatic Biology, 5(2): 79-94.

Sharma, B.K., PoU, K.R.S. \& Sharma, S. (2016): Rich rotifer assemblage (Rotifera: Eurotatoria) of a subtropical wetland of Meghalaya, northeast India: ecosystem diversity and interesting features. International Journal of Aquatic Biology, 4(3): 179-188.

SHARMA, B.K. \& SHARMA, S. (1999): Freshwater rotifers (Rotifera, Eurotatoria). Fauna of Meghalaya, State Fauna Series, 4(9): 11-161.

SHARMA, B.K. \& SHARMA, S. (2000): Freshwater rotifers (Rotifera, Eurotatoria). Fauna of Tripura, State Fauna Series, 7(4): 163-224.

SHARMA, B.K. \& SHARMA, S. (2014a): Northeast India - An important region with a rich biodiversity of Rotifera. In. SHARMA, B.K., DUMONT, H.J \& Wallace, R.L. (Eds.) Rotifera XIII: Rotifer Biology - A structural and functional Approach. International Review of Hydrobiology, 99(1-2): 2037. doi: 10.1002/iroh.201301701

SHARMA, B.K. \& SHARMA, S. (2014b): Floodplains of the Brahmaputra river basin-globally interesting ecotones with rich Rotifer (Rotifera: Eurotatoria) biodiversity. In. SINHA, R.K. \& AHMED, B. (Eds.) Rivers for Life - Proceedings of the International Symposium on River Biodiversity: GangesBrahmaputra-Meghna River System, Ecosystems for Life. A Bangladesh-India Initiative, International Union for Conservation of Nature, p. 258-270.

SHARMA, B.K. \& SHARMA, S. (2015): Biodiversity of freshwater rotifers (Rotifera: Eurotatoria) of Mizoram, Northeast India: composition, new records and interesting features. International Journal of Aquatic Biology, 3(5): 301-313.

SHARMA, B.K. \& SHARMA, S. (2017): Rotifera: Eurotatoria (Rotifers). In. CHANDRA, K., GOPI, K.C., RaO, D.V., VAlarmathi, K. \& ALFRED, J.R.B. (Eds.) Current status of freshwater faunal diversity in India, Zoological Survey of India, Kolkata, Chapter 7: 93-113. 
SHARMA, B.K. \& SHARMA, S. (2018a): Loktak Lake, Manipur revisited: A Ramsar site as the rotifer (Rotifera: Eurotatoria) biodiversity hot-spot of the Indian sub-region. Bonn zoological Bulletin, 67(1): $5-13$.

Sharma, B.K. \& Sharma, S. (2018b): The rotifers (Rotifera: Eurotatoria) from the Kashmir Himalayan floodplains and Rotifera biodiversity of Jammu \& Kashmir, north India. International Journal of Aquatic Biology, 6(4): 208-220.

SHARMA, B.K. \& SHARMA, S. (2019): The biodiverse rotifer assemblages (Rotifera: Eurotatoria) of Arunachal Pradesh, the eastern Himalayas: alpha diversity, distribution and interesting features. Bonn zoological Bulletin, 68(1): 1-12. doi: 10.20363/BZB2019.68.1.001

SHARMA, BK., SHARMA, S. \& HATIMURIA, MK. (2015): Rotifer assemblages (Rotifera: Eurotatoria) of the floodplain lakes of Majuli River Island, the Brahmaputra river basin, northeast India. International Journal of Aquatic Biology, 3(1): 1-13.

SHARMA, S. \& SHARMA, B.K. (2008): Zooplankton diversity in floodplain lakes of Assam. Records of the Zoological Survey of India, Occasional Paper No. 290: 1-307.

Sharma, S. \& Sharma, B.K. (2013): Faunal diversity of aquatic invertebrates of Deepor Beel (a Ramsar site), Assam, northeast India. Zoological Survey of India, Kolkata, Wetland Ecosystem Series, 17: 1-226 pp. 